Bogdan Gregor

Magdalena Kalińska-Kula

University of Lodz

\title{
MARKET INTELLIGENCE - A CONCEPTUAL APPROACH
}

Nowadays the biggest challenge for managers is obtaining business information that should support decision-making processes. The main task of decision makers is to understand the operating environment in order to compete effectively and as a result, to achieve success and development. Market intelligence as a practical program collects information about the market and its players through constant monitoring of the environment and ongoing changes that are observed, as well as in a form of ad hoc projects. Nowadays market intelligence in many companies has reached a position that compares to other professional management support functions, such as risk management or public relations.

The aim of the article was to provide an explanation of the essence of market intelligence as a concept that plays a crucial role in generating valuable knowledge about the market, building competitiveness of enterprises and achieving growth in a specific market. The authors present the results of introductory research on functioning of programs used for obtaining knowledge about the market in regional enterprises. The research was conducted in big and medium-sized enterprises in Lodz province by means of a personal interview and a measurement tool was a questionnaire.

Key words: market intelligence, marketing research, market research, knowledge on the market

\section{Introduction}

To understand the market, to undertake a successful competitive struggle and to develop - these are the challenges that managers face today. Business environment is getting more and more complex, complicated and multidimensional. Every organization is an element of a chain of values including customers, intermediaries, suppliers and various competitors. An enterprise cooperates with specific groups such as government institutions or trade associations. All these entities create industries whose dynamics must be understood by enterprises. Apart from that the macroeconomic environment must be taken into consideration, including economic, demographic, cultural factors as well new technologies which, similarly to business models, can be easily transferred to adjacent industries. Trends and megatrends that appear in the environment initiate creating new business opportunities and threats, both now and in the future. In order to create a strategy of development every organization should understand current and expected changes that are observed in the market.

In the global survey concerning market research conducted in 2009 by Global Intelligence Alliance 724 managers and specialists indicated opportunities and threats 
that must be taken into account. ${ }^{1}$ The issues that were most often mentioned among opportunities included mergers and acquisitions, taking over competitors' market share, expansion to new markets, discovery of innovative business models, a proper recognition of customers' expectations and new needs as well as generating a new partnership. As far as the problems that managers face are concerned, they indicated such threats as a fall of prices, new rivals in the market, new business models, consolidation or fragmentation of a value chain, lack of understanding of current trends, changes in consumers' behaviour.

Taking into account how complex the environment in which modern organizations act is, it must be assumed that competitiveness and enterprise development to a large extent are conditioned by a careful examination and understanding of business environment. That task may seem difficult because together with a growth of complexity of global market, an amount and range of available market information increase dramatically. Lots of managers feel some symptoms of information paralysis and every additional item of information only hinders finding and recognition of correct data that might be used in decision-making processes.

Management of business information in such circumstances boils down to an ability to obtain proper data from organisation environment and to transform it into knowledge that can help in managerial decisions. Another challenge is also the management of a growing amount of information that already is inside an organization in the form of knowledge and experience of employees at different levels. Decision makers should skillfully use these resources and do it in a methodical way. While taking an aspect of time into consideration, it must be added that it is crucial to obtain appropriate business information at the right time - when it is exactly needed to make a decision. Against the background of such conditions it is clearly observed that there is a need to find effective solutions for managers. Market intelligence can be such a solution as it is understood as a program of specific actions and a function of supporting decision making processes occurring within enterprise management.

The aim of the article was an attempt to explain the essence of market intelligence as a concept that plays a crucial role in generating valuable knowledge about the market. Apart from a theoretical discussion that was based on studies of literature, the paper presents introductory results of the research concerning functioning of programs for obtaining knowledge about the market in regional enterprises. The research was conducted on the sample of big and medium-sized enterprises from Lodzkie province by means of a personal interview. The research was financed from statutory funds of the Department of Marketing of the University of Łódź.

\section{The essence of market intelligence and related concepts}

It can be assumed that market intelligence is at the same time a kind of old and new area. The conception was born when the first entrepreneur decided to implement the idea of systematical gathering information on the structure of its organization. But it was at the

\footnotetext{
${ }^{1}$ H. Hedin, I. Hivensalo, M. Vaarnas: The Handbook of Market Intelligence, John Willey \& Sons Ltd, Chichester 2011, p. 4.
} 
turn of the previous century's last years when the development of Market Intelligence accelerated rapidly, and this concept began to appear in the literature.

All organizations functioning in a competitive environment need and have always needed information what the market wants, what products and services consumers expect as well as what competition offers. Their objective is to strive to gain a competitive advantage. However, activities in the area of market intelligence are sometimes perceived in a narrow sense and are limited to „keeping an eye" on the competition and activities are undertaken haphazardly by individual people in various departments of organisation. Nowadays, the conditions of the global economy impose a necessity to implement systematic programs of collecting information. Information must be adjusted to a functional area of organization (finance, marketing, human resources management, etc.) as well as to a function and level of management. Every decision making level in an enterprise requires an inflow of specific information at the right moment. ${ }^{2}$ Due to an increasing need for precise and adequate business information that is reported not only at the level of head office, but virtually at every level of enterprise, market intelligence plays an important role in organisation development. It must be stressed that for the last years there has been a considerable change in information supply and decision makers today have to struggle with a risk of information disconnection caused not by the lack of information, but by the lack of time to order and differentiate available information. Managers function in the plethora of information and often have problems to identify what is really important ${ }^{3}$ and so-called ,information gap" that has been observed until recently has been transformed into overabundance of often irrelevant information, that bring information pollution. ${ }^{4}$ What proves crucial in this situation is not only an information resource but an ability to select, assess and use it is estimated that only $20 \%$ of information that reaches managers concerns key issues and in $80 \%$ it decides about the results of activities. ${ }^{5}$ That is why, among others, market intelligence today occupies a position comparable to other professional supportive functions in organizations such as risk management, public relations or outsourcing. According to the findings of the global survey conducted in 2009 by Global Intelligence Alliance in enterprises where market intelligence actions were systematically implemented, making decisions is more effective in comparison to companies where MI program does not function. $82 \%$ of respondents using market intelligence program claimed that appropriate information, necessary to support decision making processes is usually available at once or with a slight delay, whereas only $53 \%$ of respondents without this program claimed the same. ${ }^{6}$

Enterprises are market entities that dynamically try to shape their environment through operational, tactical and strategic decisions. In many organizations millions of

\footnotetext{
${ }^{2}$ T. Domański, P. Kowalski: Marketing dla menedżerów, Wydawnictwo Naukowe PWN, Warszawa-Łódż 1998, s. 71.

${ }^{3}$ A. K. Koźmiński.: Zarządzanie w warunkach niepewności, Wydawnictwo Naukowe PWN Warszawa 2004, s. 8.

${ }^{4}$ J. Sosnowski: Systemy elektroniczne w marketingu, Wydawnictwo Uniwersytetu Łódzkiego Łódź 1999, s.95. ${ }^{5}$ Z. Martyniak: Metody organizowania procesów pracy, Państwowe Wydawnictwo Ekonomiczne, Warszawa 1996, s.30.

${ }^{6}$ H. Hedin, I. Hivensalo, M. Vaarnas: The Handbook of Market Intelligence, John Willey \& Sons Ltd, Chichester 2011, p. 9.
} 
such decisions are made every day and simplicity in making them to a great extent depends on the method of organization, cohesion and complexity of information policy implemented in a company. ${ }^{7}$ Market intelligence in its essence is a process of continuous obtaining information from various sources, their evaluation, and then using it while making business decisions. It can be defined as a program of activities targeted at collecting information about market players and strategic problems and subsequently, processing it into observations and knowledge supporting decision-making processes in an enterprise. These activities play a key role in generating knowledge about the market, building competitiveness and company development while helping an organisation to understand the environment in which it functions, to compete successfully in this environment and as a result, to achieve growth. ${ }^{8}$

Information grounds of market intelligence are formed by four basic areas: information about a product, about competition, about the market and information about consumers. ${ }^{9}$ Information about a product refers to knowledge about products available on the market that an enterprise supports and concerns tactical marketing activities such as a pricing policy or a promotional action applied for the products (both, its own and rival products). The area of information about competition comprises understanding of competitors' strategy, investments and development plans, organizational structure, portfolio of current and future products. In turn, information concerning the market comprises its picture at a macroeconomic level as well as determination of the market size and its segments, trends concerning market shares, development trends and forecasts for the market growth.

The area of information about consumers is associated with understanding preferences of buyers and reasons for their behaviour and opinions that can influence their actions and an attitude to products or services of a company as well as studies on brand awareness, level of satisfaction and customer loyalty and dynamics of sales. Each of the mentioned areas could be a separate area for analysis, however, the essence of market intelligence is rooted in combining information so that a complete picture of the market could be created.

In order to present a complex picture of the market where an enterprise functions, which comprises first of all its clients and competition as well as conditions for a growth potential for new products and services, market intelligence takes advantage of many sources of information. Sources of data for this type of analysis include sales journals, findings of conducted surveys, social media research and many others. Information can be collected from business and industry associations, state institutions or by visiting a website or competitors' shops, finding information published in the press about a number and type of potential customers. Market intelligence also comprises checking commentaries made by customers that are passed on via the Internet and collecting information that could help a company to improve its offer. While gathering knowledge about the market many companies applied advanced analyses forgetting that a potential source of valuable data are customers. Even small companies can create

\footnotetext{
${ }^{7}$ M. Callingham: Market Intelligence, Kogan Page Ltd, London 2004, p. 9.

${ }^{8}$ H. Hedin, I. Hivensalo, M. Vaarnas: The Handbook of Market Intelligence, John Willey \& Sons Ltd, Chichester 2011, p. 9.

${ }^{9}$ E. Crowley: Market intelligence versus marketing research, Quirk's. Marketing Research Review 12/2004, p. 64.
} 
customers' databases and implement programs for collecting customers' opinions creating resources of knowledge about buyers in an efficient and cheap way (customer intelligence). ${ }^{10} \mathrm{~A}$ potential source of valuable information are also analytical ecommerce systems that allow to track buyers' behaviour on an enterprise website e.g. to obtain information about how many people visit a website, where they come from, what the subsequent steps after entering a website are, how many of them reach a basket of shopping and how many leave a website without making a transaction. In order to create the most complete picture of the market, specialists of market intelligence should also collect data while communicating with producers, distributors and all intermediaries engaged in a process of creating products and making them available. This kind of dialogue and statistical data and results of marketing research constitute a crucial part of market intelligence system.

While building key competencies in the area of market intelligence a key role is assigned to outsourcing, sometimes referred to as „lean management”, , e.g. in the range of using external suppliers of technologies of information distribution used for collecting, analyzing and spreading data about current market changes (regarding prices of competition or promotional actions). It is also possible to use a marketing research agency to implement all side aspects of research projects (including collecting empirical data, project management and conducting basic and cross statistical analyses). On the other hand, analysts in an enterprise can concentrate on preparing an initial research project based on thorough understanding of information needs of managerial staff, and then transferring research results into recommendations towards specific business decisions. Application of appropriate rules, techniques and solutions enable to create a structure of market intelligence but not only those present an integral part of a process of making a decision, but also the ones that play a key role in shaping strategic directions of enterprise development. $^{12}$

The notion of market intelligence is related to other activities and is often identified with them. The term is frequently used interchangeably with the notion of marketing research, which is a mistake. ${ }^{13}$ Marketing research comprises various forms and methods of activities whose aim is to increase understanding of market and customers and they constitute an explicitly defined discipline with the grounds in business practice. Market intelligence presents much a broader notion - a continuous process of acquiring holistic knowledge to obtain a comprehensive picture of all aspects of the market. The basic differences between marketing research and market intelligence include: ${ }^{14}$

\footnotetext{
${ }^{10} \mathrm{~K}$. Arline: What is Market Intelligence? Business News Daily, http://www.businessnewsdaily.com, data dostępu: 10.02 .2015

${ }^{11}$ G. Probst, S. Raub, K. Romhardt: Zarządzanie wiedzą w organizacji, Oficyna Ekonomiczna Kraków 2002

${ }^{12}$ E. Crowley: Market intelligence versus marketing research, Quirk's. Marketing Research Review 12/2004, p. 66 .

${ }^{13}$ J. Weber, J. Spitzner, M. Staffels: Erfolgreich steuern mit Market Intelligence. Marktentscheidungen fundiert treffen, Wiley-VC Verlag, Weinheim 2008, p.5.

${ }^{14}$ E. Crowley: Market intelligence versus marketing research, Quirk's. Marketing Research Review 12/2004, p. 64.
} 
- market intelligence is an all-embracing activity and collecting data is only one of the aspects of this activity. Research can be a fundamental element of building ,information pyramid" but not the only one;

- analyses conducted within the framework of market intelligence require greater analytical and business skills than in the case of traditional marketing research. What is indispensable is integration of data concerning the market, key competitors, financial dynamics of industry as well as the whole chain of enterprise value. To carry out such extensive analyses people with appropriate skills and competences are needed - managerial, financial, mathematical, sociological ones as well as knowledge of product management of consumer behaviour;

- market intelligence requires integration of all areas of enterprise activity and comprises the overall picture of the market whereas marketing research strictly focuses on specific problems;

- marketing research usually concentrates on providing answers to specific questions or to solve specific problems and it presents a completed „task”, whereas market intelligence is a continuous, interactive process that is a closed system and encompasses feedback from managerial staff for a market intelligence team. These teams constantly monitor the environment, detect and synthesize information, thanks to which managerial team is not astonished with the development of market situation or actions of competition.

As it has been already mentioned, market intelligence enables to gain permanent and full understanding of the market. Each area of collected knowledge about competition (competitor intelligence), a product (product intelligence), market (market understanding) and customers (customer insight) - is indispensable to fully understand the environment in which an enterprise functions. Strategies of every market participant influence activities undertaken in a product area. Trends of market development and reactions of segments subsequently determine strategies of competing enterprises and behaviour and attitudes of customers drive the dynamics of the market, its pace of development and acceptance of a product. Therefore, the integration of all indicated areas of knowledge is of crucial importance. Marketing research plays a significant role in obtaining information, however, it does not integrate all information areas, which are encompassed by market intelligence. If a company narrows activities only to marketing research, its view on the market is limited to specific problem areas. This is the range of information covered by the analysis that is one of the key differences between marketing research and market intelligence.

The notion of market intelligence is sometimes used interchangeably with the notion of business intelligence although BI refers more often to computer systems and techniques of processing of figures. Systems of business intelligence enable an analysis of data concerning mostly customers and lines of products, amount of distributed goods or volume of sales in a specific period of time. On the other hand, market intelligence concentrates on specific categories of customers, taking into the account their segmentation by demographic and geographical criteria as well as habits and purchasing 
behaviour and it also takes into consideration what happens with competition, which is an area omitted by business intelligence. ${ }^{15}$

As it has been observed, tracking competition and a condition of industry is an integral element of activity of each company. Traditionally, obtaining this type of information was described as market research. Considering their essence these two notions are to a great extent convergent. Market research aims to decrease entropy and disorder of a market entity, is orientated at the inside of an organization and serves to recognize a market situation and to determine an enterprise's own share. ${ }^{16}$ It constitutes a complex process that consists of subsequent steps of groups of activities for collecting information, processing gathered data, analysis and interpretation of obtained findings. ${ }^{17}$

Within the framework of market research two areas can be distinguished market analysis and forecasting. The first of them serves to learn about current phenomena and market processes and it comprises an analysis of market balance, market capacity and absorption. Forecasting, on the other hand, through capturing dynamic changes observed in demand, which depend on various economic and non-economic factors, allows predicting a future market condition. ${ }^{18}$ In case of market intelligence the practice of collecting information presented above, has been extended by a range of analyses directed at improvement of enterprise business model and its development perspectives. On the basis of collected information it can be stated that these phenomena coexist and cause and effect interdependencies can be determined and that knowledge creates the grounds for building a model that enables the quantification of market reality. Based on the created model one can make forecasts of development of market phenomena in the future, which becomes a crucial element of the decision support system. $^{19}$

The practice of international research can also seem convergent with the concept of market intelligence. Plenty of companies place international marketing research within the framework of their market intelligence systems and processes, however, these notions are not identical. Enterprises undertake international research in order to collect information about a local target market. The objective of this research is to provide crucial data for enterprises that concern specific needs of buyers, market size and competition. Global market research is to provide information that serves to determine profitability of a venture or a product before they invest bigger resources and enter a specific market. Such research can obviously be conducted both, before and after launching a product to a new market, yet, it is especially important before making international expansion because it shows companies a correct direction of strategy. Contrary to international research, market intelligence puts emphasis on information that is adequate for current markets where an enterprise functions and processes it into knowledge that serves to support managerial decisions. ${ }^{20}$

\footnotetext{
${ }^{15} \mathrm{~K}$. Arline: What is Market Intelligence? Business News Daily, http://www.businessnewsdaily.com, data dostepu: 10.02.2015

${ }^{16}$ S. Mynarski: Przesłanki badań rynkowych i marketingowych, Marketing i Rynek 12/1998, s. 4.

${ }^{17}$ Z. Kędzior [red.]: Badania rynku, Polskie Wydawnictwo Ekonomiczne, Warszawa 2005, s. 7.

${ }^{18}$ S. Mynarski: Przesłanki badań rynkowych i marketingowych, Marketing i Rynek 12/1998, s. 5.

${ }^{19}$ H. Mruk [red.]: Analiza rynku, Polskie Wydawnictwo Ekonomiczne, Warszawa 2003, s. 13.

20 K. Pham: International Market Research versus International Market Intelligence, http://internationalmarketintelligence.com, data dostępu: 10.06.2015
} 


\section{Material and methods}

In light of studies on the literature market intelligence is a concept that plays a critical role in generating valuable knowledge about the market, building enterprise competitiveness as well as achieving growth in a current market. A fundamental question that was raised against this background concerned a degree and range of functioning of market intelligence and application of practices serving to build this type of systems among local enterprises. In order to gain an answer to this question a research project was designed and its first stage were literature studies. Then, the introductory research was prepared and conducted by means of personal interviews with managers and managerial staff of big and medium-sized enterprises located in the Lódź Province. The measurement tool was a questionnaire that comprised both open and closed questions and the interviewer was able to modify questions and to ask some additional ones. The research was conducted in the period between October 1 and November 15, 2015 and it included 45 business entities. Due to a relatively small size of the sample the generalizing value of the research findings is limited, nonetheless, they served to prepare a research instrument that will be used in the subsequent stage of the quantitative research.

The enterprises included purposefully in the research sample were big and medium-sized enterprises, taking an assumption that only such entities can possess information indispensable to realize the research objectives. Nearly three quarters of the sample were companies that employ between 50 to 249 workers - 33 enterprises. The sample comprised also 7 entities employing from 250 to 500 workers and 5 entities with more than 500 employees. More than a half of the surveyed enterprises were manufacturers (26 entities), a quarter ran trading activity ( 7 wholesalers and 4 retailers), whereas 7 - ran service activities. Nearly $60 \%$ of respondents (27 entities) are companies active in B2B sector, more than a quarter - in B2C sector (13 companies), and 5 enterprises indicated public administration sector as their target market (B2G). The vast majority (nearly two thirds) of enterprises, which participated in the research, conduct activities on an international scale, one fifth (10 entities) function in the domestic market and only 7 - in a regional market. More than a half of respondents are companies exclusively with Polish capital, slightly above one quarter indicated mixed capital and 7 entities were companies exclusively with foreign capital.

\section{Results and discussion}

In the course of conducted studies respondents were asked to what extent information about the market obtained by means of market research can be helpful in such issues as sales increase, reduction of risk connected with making decisions, obtaining competitive advantage, extension of target market, improvement of enterprise image, building permanent relations with buyers, creating ideas and development of new product as well as launching a product. According to the surveyed, knowledge about the market can prove useful to achieve growth of sales - such opinions were mentioned by over $80 \%$ of enterprises (among which nearly half of respondents said it was ,very helpful”). Three quarters stated that market research was helpful or very helpful in gaining a competitive advantage as well as in creating ideas for a new product. Two out of three respondents 
expressed such opinions about their extending target market and improvement of enterprise image, and over $60 \%$ indicated reduction of risk and launching a new product to a market. Over a half of respondents also expressed opinions that market knowledge is helpful or very helpful in building permanent relations with buyers.

Subsequently, the respondents were asked about facts concerning the practice of gaining knowledge about the market. In light of the research findings the information that was collected most often concerned competition (more than nine out of ten surveyed companies). A high proportion i.e. over $80 \%$ of respondents collected also information about buyers to support managerial processes, three quarters collected information concerning their target market and slightly over two thirds $(68.9 \%)$ - information concerning products. Only in case of information regarding promotional activities the proportion of indications was lower than $42.2 \%$.

In case of studies on competition the most frequent actions included activities meant to monitor current activities of competition (more than a half of respondents conduct such studies regularly - every month or every quarter at the latest) including activities connected with launching new competitive products to the market (nearly $40 \%$ of respondents). Every third of surveyed enterprises conduct studies on consumer strategy regularly and every fifth - the analysis of a subjective structure of competition in a current market. Studies on a market share as well as organizational structures of competitors are conducted by the majority (more than a half) of respondents ad hoc or once a year.

As far as knowledge about buyers is concerned, enterprises most often conduct research of needs and preferences as well as customer satisfaction - above $40 \%$ collect this type of information regularly every month or every quarter. However, studies on loyalty are conducted regularly only by every fourth enterprise, whereas nearly two thirds conduct measurements in this area only once a year or ad hoc. Research on consumer behaviour in the process of buying is carried out by every fifth company and every third do not conduct this type of studies at all. Nearly half of respondents never examine consumers' features and their sensitivity to changes in income and prices and more than a half do not conduct motivational research.

As far as the recognition of enterprise target market is concerned, the most frequent studies concern market trends which are conducted regularly by more than a half of companies. On the other hand, market forecasts are prepared regularly by nearly half of respondents, similarly to the analysis of their own market shares. Slightly over one third of respondents conduct research on a territorial range of the market and analyse opportunities and threats emerging in the market environment of an organization. Three quarters of enterprises examine ad hoc or regularly the market size and potential, and more than a half conduct segmentation research with a similar frequency. Analysis of market in space is conducted ad hoc by nearly half of companies and the same number does not carry out such research at all.

The vast majority of surveyed enterprises - nearly two thirds - regularly conduct research connected with shaping a product price and dynamics of sales. Nearly a half of companies equally often conduct research on perception of a product and its quality as well as on the level of provided services. Analyses in the area of distribution and logistics as well as the research on brand awareness and recognition are carried out regularly by more than $40 \%$ of respondents. Studies that are conducted the most rarely 
concern brand preferences and are realized by nearly a half of enterprises, whereas one third do not conduct such measurements at all.

As far as promotional activities are concerned nearly $60 \%$ of enterprises regularly conduct analyses of efficiency and effectiveness of their activities and studies on communication are realized by more than a half of respondents. At the same time, nearly half of companies undertake research on consumers' sensitivity to instruments of promotion ad hoc, whereas studies on media are not conducted by more than a half of companies at all.

In the course of conducted studies there was an attempt to determine who in the surveyed enterprises (organizational unit or a specific person) is responsible for coordinating and conducting market research and analyses. Respondents most often pointed at marketing department (nearly half of the surveyed) and sales department (nearly one quarter), more seldom they indicated heads of departments and directors (only every fifth enterprise), and even more seldom they indicated the board, auditors or ISO department and IT department. It must be observed that in light of the literature studies, organizationally market intelligence is usually placed in the area of strategic planning, business development or marketing, which was also confirmed in quoted results of the research. ${ }^{21}$

As far as the number of people involved in collecting market information is concerned, in majority of enterprises there were $3-4$ people (it was indicated by more than $60 \%$ ), one fifth of organizations delegate a dozen workers for these tasks (usually $14-15$ people). It must be noted that there are companies that have a team of 20,30 , or even 50 people, who deal with obtaining knowledge of the market. According to the results of the research cited before i.e. the one conducted by Global Intelligence Alliance, an average size of market intelligence team was 13 people. ${ }^{22}$ It is worth mentioning that only one third of examined enterprises used external companies to obtain market information, and the others conducted that research on their own.

In order to create a full picture of the market in which an enterprise functions, of their customers and competition, a system of market intelligence should use a lot of sources of information. The surveyed enterprises indicated using secondary sources, such as own records (i.e. sales journals, reports), which were evaluated as very useful by the vast majority of companies $(80 \%)$. Websites were also mentioned - they were considered useful by nearly a half of respondents as well as social media and institutional sources of data that are available in various offices, institutions, yet, the two last categories were evaluated as the least useful by nearly half of respondents.

Respondents also collected information from primary sources, such as customers (this source was considered useful by more than nine out of ten surveyed), business partners, including suppliers and intermediaries (a very useful source according to three out of four surveyed), distributors (two thirds of respondents expressed very positive opinions) as well as consultants and specialists in a specific industry including producers (evaluated as a very useful source of data by one third of respondents). It must

\footnotetext{
${ }^{21}$ H. Hedin, I. Hivensalo, M. Vaarnas: The Handbook oh Market Intelligence, John Willey \& Sons Ltd, Chichester 2011, p. 12.

${ }^{22}$ H. Hedin, I. Hivensalo, M. Vaarnas, The Handbook oh Market Intelligence, John Willey \& Sons Ltd, Chichester 2011, p. 14.
} 
be emphasized that all enterprises included in the research stressed that in order to obtain necessary information they conducted empirical research. Among methods used by them the dominant ones were observations $(90 \%)$, individual interviews (more than two thirds of respondents), and questionnaires (more than a half). Focus group interviews were used very rarely.

The vast majority of respondents (nearly two thirds) expressed an opinion that obtained market information satisfies information needs in their company. Collected information about the market enabled - according to $80 \%$ of enterprises - to satisfy customers' needs better, to expand a market as well as to specify or modify the plans of enterprise. Nearly three quarters of respondents claimed that this information helped them to achieve such objectives as growth and development of an enterprise or to gain a competitive advantage. Two thirds of enterprises stated that it was useful in building a company image as well as in reducing the risk of investment decisions.

At the same time nearly half of respondents confirmed that collected knowledge was definitely more helpful in making decisions, and more than a half claimed that conducting market research in order to obtain market information is profitable for a company (i.e. achieved benefits exceed incurred costs). Managers were asked about costs that an enterprise must pay in a year to collect market information (taking into account total costs of conducted research, purchase of information, purchase or usage of analytical software and tools as well as services of specialists and analysts, etc.). One quarter of respondents refused to answer this question, whereas every third of the surveyed mentioned the amount of up to 10000 zloty and a similar proportion indicated the amount between 10000 zloty to 100000 zloty. Only two of examined entities spend more than 250000 zloty on obtaining market information.

As the basic objective of gathering knowledge about the market is to facilitate making proper decisions supported by adequate information for an enterprise, at the end of the research respondents were asked to evaluate decision-making processes in their companies. The vast majority of respondents (nearly 90\%) claimed that making managerial decisions in their organizations is very effective, and more than three quarters - that all managerial decisions are supported by appropriate market information. Nearly half of respondents claimed that too much information is not a problem for a company and decisions are never delayed because of a lack of data. On average, every third company confirmed that information about business environment is always easily available in a company and that the problem of inaccurate or insufficient information does not exist.

\section{Conclusion}

As it has been already observed, the presented findings are the effect of introductory measurement which served to recognize the topic of the presented discussion as well as to prepare a tool for a subsequent stage of quantitative research that will be conducted on a bigger sample. The introductory research was purely of a descriptive character and due to a relatively small size of the sample it was impossible to conduct the analysis of cause and effect dependencies. That is why it is not possible to state unequivocally to what extent conducting systematic market research and implementation of complex market 
intelligence programs translate into a more effective decision-making. Therefore, this problem will be the subject of further studies.

\section{References}

Arline K.: What is Market Intelligence? Business News Daily, http://www.businessnewsdaily.com, data dostępu: 10.02.2015

Callingham M.: Market Intelligence, Kogan Page Ltd, London 2004

Crowley E.: Market intelligence versus marketing research, Quirk's. Marketing Research Review $12 / 2004$

Domański T., Kowalski P.: Marketing dla menedżerów, Wydawnictwo Naukowe PWN, Warszawa-Łódż 1998

Hedin H., Hivensalo I., Vaarnas M.: The Handbook of Market Intelligence, John Willey \& Sons Ltd, Chichester 2011

Kędzior Z. [red.], Badania rynku, Polskie Wydawnictwo Ekonomiczne, Warszawa 2005

Koźmiński A. K.: Zarządzanie w warunkach niepewności, Wydawnictwo Naukowe PWN

Warszawa 2004

Martyniak Z.: Metody organizowania procesów pracy, Państwowe Wydawnictwo Ekonomiczne, Warszawa 1996

Mruk H. [red.]: Analiza rynku, Polskie Wydawnictwo Ekonomiczne, Warszawa 2003

Mynarski S.: Przesłanki badań rynkowych i marketingowych, Marketing i Rynek 12/1998

Pham K.: International Market Research versus International Market Intelligence,

http://internationalmarketintelligence.com, data dostępu: 10.06.2015

Probst G., Raub S., Romhardt K.: Zarządzanie wiedzą w organizacji, Oficyna Ekonomiczna

Kraków 2002

Sosnowski J.: Systemy elektroniczne w marketing, Wydawnictwo Uniwersytetu Łódzkiego Łódź 1999

Weber J., Spitzner J., Staffels M.: Erfolgreich steuern mit Market Intelligence.

Marktentscheidungen fundiert treffen, Wiley-VC Verlag, Weinheim 2008

\section{Market Intelligence - ujęcie konceptualne}

\section{Streszczenie}

W dzisiejszych czasach wyzwaniem dla menedżerów jest pozyskiwanie szeroko rozumianej informacji biznesowej służącej wsparciu procesów decyzyjnych. Zadaniem decydentów jest rozumieć otoczenie, w którym funkcjonuje organizacja, skutecznie konkurować, a w rezultacie osiagać sukces i rozwój. Market intelligence jako praktyczny program działań umożliwia pozyskanie informacji o rynku i jego uczestnikach, poprzez ciąłłe monitorowanie otoczenia i bieżących zmian, które w nim zachodzą, jak również w formie projektów realizowanych ad hoc. Obecnie market intelligence osiaga $\mathrm{w}$ wielu organizacjach pozycję porównywalną do pozycji innych funkcji wspierających procesy zarządcze, takich jak zarządzanie ryzykiem czy public relations.

Celem artykułu było wyjaśnienie istoty market intelligence, jako koncepcji pełniącej krytyczną rolę w generowaniu wartościowej wiedzy o rynku, budowaniu konkurencyjności przedsiębiorstwa oraz osiaganiu wzrostu na obsługiwanym rynku. Przedstawione zostały także wyniki wstępnych badań na temat funkcjonowania programów pozyskiwania wiedzy o rynku w rodzimych przedsiębiorstwach. Badanie przeprowadzono wśród dużych i średnich przedsiębiorstw województwa łódzkiego, za pomocą metody wywiadu osobistego, a narzędziem pomiaru był kwestionariusz wywiadu. 
Słowa kluczowe: market intelligence, badania marketingowe, badania rynku, wiedza o rynku

Informacja o autorach:

Prof. dr hab. Bogdan Gregor

Dr Magdalena Kalińska-Kula

Uniwersytet Łódzki

Wydział Zarządzania

ul. Matejki 22/26

90-237 Łódź

e-mail: kalinskam@uni.lodz.pl 